JOURNAL OF SECURITY AND SUSTAINABILITY ISSUES ISSN 2029-7017 print/ISSN 2029-7025 online 2020 June Volume 9 Number 4 https://doi.org/10.9770/jssi.2020.9.4(31)

Scopus

\title{
ENSURING ECONOMIC SECURITY OF UKRAINE IN THE SPHERE OF FOREIGN ECONOMIC ACTIVITY
}

\author{
Dmytro Zhuravlov', Ivan Lytvyn ${ }^{2}$, Oleksandr Ilchenko ${ }^{3}$, Ivan Yaromii ${ }^{4}$, Yuliia Lepekh ${ }^{5}$ \\ ${ }^{1 *}$ Institute of Law and Postgraduate Education of the Ministry of Justice of Ukraine, \\ Silovych Street, 73, Kyiv,04053, Ukraine \\ ${ }^{2}$ Kropyvnytskyi Institute of State and Municipal Administration, 73, Nicholas Levitsky, Kropyvnytskyi, 25026, Ukraine \\ ${ }^{3}$ Sumy State University, 2 Rimsky-Korsakova Street, Sumy, 40000, Ukraine \\ ${ }^{4}$ Security Service of Ukraine in Lviv Region, Dmytro Vitovskoho Street, 55, Lviv, Lviv Region, 79000, Ukraine \\ ${ }^{5}$ Interregional Academy of Personnel Management, Hetman Mazepa Street, 29, Lviv, 79000, Ukraine
}

E-mail: ${ }^{*}$ koaduep@gmail.com (Corresponding author)

Received 18 October 2019; accepted 20 March 2020; published 30 June 2020

\begin{abstract}
The nature study of customs regulation in modern conditions has lead to the need for theoretical bases and practical recommendations for the implementation of an effective mechanism of the state economic security, because in the context of improving the challenges of globalization, characterized by a simultaneous increase of scales and expansion of geography of international trade and labor migration, openness of national economies, revitalize the integration processes, there is an increased influence on the economic system of the state and society threats in the external environment. The concept of "customs security" is defined at the doctrinal level by covering the scientific approaches to its interpretation, as well as its interpretation at the level of the current Ukrainian legislation. Particular attention is paid to the issues of codification of EU customs legislation. The legal status of The World Customs Organization (WCO) as an independent intergovernmental body and priority areas of activity under the Strategic Plan for the period 2019-2022 have been determined. Despite the implementation of further steps to harmonize Ukrainian customs law with the European, the creation of favorable business conditions for the subjects of foreign economic activity (FEA) justified the expediency of developing a concept of ensuring economic security in the sphere of FEA on the bases of balancing economic interests, which is based on the search for a compromise between the measures of control of revenue and fees to ensure economic security in the sphere of FEA and providing business simplifications taking into account the economic interests.
\end{abstract}

Keywords: economic security; customs security; foreign economic activity; customs regulation; economic interests.

Reference to this paper should be made as follows: Zhuravlov, D., Lytvyn, I., Ilchenko, O., Yaromii, I., Lepekh, Y. 2020. Ensuring economic security of Ukraine in the sphere of foreign economic activity. Journal of Security and Sustainability Issues 9(4), $1497-1512$. https://doi.org/10.9770/jssi.2020.9.4(31)

JEL Classifications: F35, F42

\section{Introduction}

In the context of improving the processes of globalization, characterized by a simultaneous increase of scales and expansion of geography of international trade and labor migration, openness of national economies, revitalize the integration processes, there is an increased influence on the economic system of the state and society threats in the external environment (Šincāns et al., 2016; Fakhry et al., 2018; Tvaronavičienè, 2018; Plèta et al., 2020; Chehabeddine, Tvaronavičienè, 2020; Lincényi, Čársky, 2020).

In order to evening-out and form an adequate response to these threats, there are being transformed the content and function of state customs affairs. 
In modern conditions, the governments of many countries face the problem of searching a balance to ensure the economic security of the national economy and providing simplifications to subjects of foreign economic activity (FEA). According to international agreements and conventions on issues of international trade, it is planned to further expand the list of simplifications for business, which are aimed at reducing the interference of customs administration officials in the foreign economic activity of economic entities. In this context, at the level of national governments and state integration associations, modern instruments are being developed and implemented to detect and prevent customs violations by unscrupulous FEA entities and to maximize assistance to entities with a high degree of confidence.

The strategic European integration course of Ukraine before joining the European community requires the protection of national interests of the country. From the content of Art. 17 of the 1996 Constitution of Ukraine: ensuring economic security is one of the most important functions of the state (Constitution of Ukraine, 1996). The activities of state bodies to protect the economic interests and economic security of the country are an integral part of ensuring national security. The emergence of external threats to the national security of the state requires not only rapid response, but also existence of effective mechanisms to counteract the possible causes of these phenomena of negative consequences.

Protection requires the vital values and interests of both societies in particular and the state on the whole. In this context, an important area is to ensure the customs security of the state, which provides the protection of society from prohibited, dangerous and substandard products, formation of the adequate level of competitiveness of the country in the world market, promotion of investment attractiveness of Ukraine and its regions, protection of interests of business entities, etc. The implementation of customs security functions rests with the relevant state structures - customs authorities. Based on the above, it is relevant to study the concept of customs security, legal status and features of the functioning of customs authorities in the context of ensuring national security of the country.

\section{Literature Survey}

The priority task of any state is the protection of its national interests. In the context of globalization and European integration processes, the economic security of the country comes first. This is due to the fact in particular that the financial and economic security of the state ultimately influences its positioning in the world (Reznik et al., 2020). The efficiency of the functioning of state customs authorities, including the organizational aspects of their cooperation with foreign countries in the direction of preventing customs offenses, depends on the legal regulation of these issues at the level of legislation. In this context, special attention is needed to ensure customs security.

Pudrik (2016) defines customs security as a status of protection of customs interests against any threats that arise in the course of state customs affairs. In turn, implementing a state customs policy envisages the regulated by legal norms executive management activities of specially authorized entities implementing state customs policy aimed at maintaning the proper status of customs interests protection against any threats arising in the course of the implementation of state customs business.

According to Levko (2016), customs security is a set of effective economic, legal, political and other mechanisms aimed at protecting the interests of economic entities and the state in the foreign economic sphere, and in particular in the customs sphere. The author draws attention to the fact that this approach determines the place of customs security in economic security, as well as its relationship with foreign economic security. The customs security mechanism is aimed at to minimize the negative impact of external and internal threats by establishing effective interaction between security entities, in particular, the customs service, and to ensure compliance by all entities with legislation.

Securing the country's customs security from the position of Crowtsky (2018) should be defined as a set of tools capable of counteracting internal and external threats and challenges in the field of customs economic relations, as well as providing the ability to achieve the necessary level of security, reliability and perseverance of the customs service by creating effective regulatory economic mechanism. 
Popivniak (2018) is of the opinion that matrimonial security should be considered as a special legal procedure for the activities of authorized entities to ensure compliance with the mandatory rules in the field of state customs business by participants of customs activity.

As a result of the investigation of the concept of customs security in the context of ensuring the national security of Ukraine Razumova (2019) concludes that customs security is a part of national security, which is characterized by a status of protection of customs interests, which is achieved through the implementation of state customs by the revenue and fees bodies. The author notes that customs security is characterized by the following features:

1) it is part of national security;

2) customs interests are a direct object of customs security;

3) security status;

4) the subject of security is the of revenue and fees bodies;

5 ) it is achieved through the implementation of state customs business.

The concept of customs security is contained in Art. 6 of the Customs Code of Ukraine at the legislative level, it is necessary to understand the status of protection of customs interests of Ukraine according to it. At the same time, customs interests of Ukraine are defined by the legislator as national interests of Ukraine, their security and implementation is achieved through the customs affairs (Customs Code of Ukraine, 2012).

\section{Methods}

The theoretical and methodological basis of the researches was formed by the general provisions of economic theory, economy and national economy management, scientific works of scientists on the issue of ensuring the economic security of the national economy.

In the process of research, there were used the following general scientific and special approaches and research methods: methods of critical analysis, scientific abstraction and generalization of scientific experience of modern theoretical researches; systematic approach (to develop conceptual provisions for ensuring economic security based on balancing the interests of the state and business); method of economic-mathematical modeling.

The information base of the research consists of legislative-statutory regulations of Ukraine, annual reports of the state fiscal service of Ukraine, the state statistics service of Ukraine, and reporting data of customs of the SFS of Ukraine.

\section{Results}

Big-bang transformations in the global political and economic space determine the need to develop new approaches to ensuring the economic security of the national economy in the face of a constant increase in threats both internal and external nature. These issues are particularly relevant for the Ukrainian economic system under constant pressure of negative factors, which requires the development and application of effective mechanisms, aimed at neutralizing, minimizing the influence and eliminating phenomena and factors that lead to the creation of external and internal threats to economic security.

It is quite difficult to ensure the effective functioning of the national economy and the economic growth without developing conceptual provisions and effective mechanism of state management in the system of economic relations of the state, aimed at avoiding threats and minimizing the influence. Under these conditions, the issue of protecting the national interests of the state in the sphere of economic security is special. The customs system occupies a special place in the mechanism of implementation of customs policy, and the customs officials of Ukraine are a specific subject of customs relations. On the one hand, they carry out state customs affairs on behalf of the state, on the other hand - they are under the administrative influence of the state. 
According to the results of these transformations, the count of customs offices changed in 2014 due to the formation of the Energy customs (liquidated in 2018), and the termination of the Crimean and Sevastopol customs offices (Figure 1).



Figure 1. Dynamics of the customs offices count and customs posts in Ukraine

Source: confirmed by the author based on Report on the implementation of the Work Plan of the State Fiscal Service of Ukraine for 2017

These institutional reforms have resulted in a reduction in the count of customs personnel (Table 1), which is significantly smaller than the count of customs administration personnel at the border of a neighboring state.

Table 1. Information on the maximum count of customs offices

\begin{tabular}{|l|c|c|c|c|}
\hline \multicolumn{1}{|c|}{ Name/year } & $\begin{array}{c}\text { On } \\
\mathbf{0 1 . 0 1 . 2 0 0 7}\end{array}$ & $\begin{array}{c}\text { On } \\
\mathbf{0 1 . 0 1 . 2 0 0 9}\end{array}$ & $\begin{array}{c}\text { On } \\
\mathbf{0 1 . 0 1 . 2 0 1 4}\end{array}$ & $\mathbf{0 1 . 0 1 . 2 0 1 7}$ \\
\hline Number of customs offices & 48 & 54 & 27 & 26 \\
\hline Personnel number of customs officials & 17958 & 17958 & 15095 & 11019 \\
\hline Personnel number of central apparatus officials & 391 & 391 & 316 & - \\
\hline
\end{tabular}

Source: confirmed by the author based on Report on the implementation of the Work Plan of the State Fiscal Service of Ukraine for 2017

As we can see from Table 2, the count of customs officials decreased by 36,9\% during 2014-2016. These aspects in the conditions of constant growth of threats of both external and internal nature reduce the security of Ukraine not only economic security of Ukraine, but also national.

Note that structural divisions of the State fiscal service (SFS) in 2016 provided revenues to the state budget in the amount of 518.3 billion UAH (Table 2). 
Table 2. Indicators of customs offices functioning of the SFS of Ukraine during 2015-2017

\begin{tabular}{|l|c|c|c|c|c|c|c|}
\hline \multicolumn{1}{|c|}{ Indicators } & $\mathbf{2 0 1 5}$ & $\mathbf{2 0 1 6}$ & $\mathbf{2 0 1 7}$ & \multicolumn{2}{c|}{ Absolute deviation } & \multicolumn{2}{c|}{ Relative deviation } \\
\cline { 5 - 8 } & & & $\mathbf{2 0 1 6 - 2 0 1 5}$ & $\mathbf{2 0 1 7 - 2 0 1 6}$ & $\mathbf{2 0 1 6 / 2 0 1 5}$ & $\mathbf{2 0 1 7 / 2 0 1 6}$ \\
\hline $\begin{array}{l}\text { Receipts (collection) of payments to the General Fund } \\
\text { of the state budget, Billion UAH, including: }\end{array}$ & 486,9 & 518,3 & 633 & 31,4 & 114,7 & 106,4 & 122,1 \\
\hline Receipts of tax payments & 284,6 & 283 & 329,1 & $-1,6$ & 46,1 & 99,4 & 116,3 \\
\hline Receipts of customs paymnents & 202,3 & 235,3 & 303,8 & 33 & 68,5 & 116,3 & 129,1 \\
\hline Foreign trade turnover, billion dollars, including:: & 74,6 & 75,2 & 92,8 & 0,6 & 17,6 & 100,8 & 123,4 \\
\hline import of goods & 36,4 & 38,9 & 49,5 & 2,5 & 10,6 & 106,9 & 127,2 \\
\hline export of goods & 38,2 & 36,4 & 43,3 & $-1,8$ & 6,9 & 95,3 & 119,0 \\
\hline $\begin{array}{l}\text { The amount of additional revenues from the } \\
\text { adjustment of customs value, billion UAH }\end{array}$ & 5,8 & 4,983 & 4,219 & $-0,817$ & $-0,764$ & 85,9 & 84,7 \\
\hline $\begin{array}{l}\text { Additional budget revenues due to classification work, } \\
\text { mln, UAH }\end{array}$ & 219,2 & 229,3 & 236,8 & 101 & 7,5 & 104,6 & 103,3 \\
\hline $\begin{array}{l}\text { Additional budget revenues from control over the } \\
\text { classification of goods at the stage after customs } \\
\text { clearance amount to mln, UAH }\end{array}$ & 28,3 & 23,2 & 5,7 & -5 Д & $-17,5$ & 82,0 & 24,6 \\
\hline $\begin{array}{l}\text { Additional revenues from control over the correctness } \\
\text { declaring the country of good's origin, mln, UAH }\end{array}$ & 81 & 84,3 & 176,5 & 3,3 & 92,2 & 104,1 & 209,4 \\
\hline
\end{tabular}

Source: confirmed by the author based on Report on the implementation of the Work Plan of the State Fiscal Service of Ukraine for 2017

Due to the implementation of effective measures aimed at achieving proper organization of customs control, effective counteraction to customs offenses, ensuring the completeness of tax administration, strengthening the control over the correctness of determining the customs value of goods, classification of goods according to the Ukrainian classification of goods of foreign economic activity (UCGFEA), the country of origin, SFS customs offices received customs payments in the amount of 303.8 billion UAH in 2017, the performance of the indicative indicator is $111.7 \%$, separately (Report on the implementation of the Work Plan of the State Fiscal Service of Ukraine for 2017):

- excise tax on excisable goods (products) imported into the customs territory of Ukraine in the amount of 40.5 billion UAH, which is $105.5 \%$ of the indicative indicator performance;

- value added tax (VAT) on goods imported to the territory of Ukraine in the amount of 250.5 billion UAH, which is $113.2 \%$ of the indicative indicator performance;

- import duty in the amount of 22.6 billion $\mathrm{UAH}$, which is $102.7 \%$ of the indicative indicator performance;

- export duty in the amount of $643.5 \mathrm{mln} \mathrm{UAH}$, which is $140.2 \%$ of the indicative indicator performance;

- single fee that is collected at checkpoints across the state border of Ukraine in the amount of $431.3 \mathrm{mln}$ UAH, which is $108.9 \%$ of the indicative indicator performance; fees for customs formalities by revenue and customs authorities outside the location of these bodies or outside work hours, set for them in the amount of $69.9 \mathrm{mln}$ $\mathrm{UAH}$, which is $98.5 \%$ of the indicative indicator performance;

One of the most effective instruments for countering customs offenses in modern conditions is cooperation and exchange of information with the competent authorities of foreign states within the framework of mutual administrative assistance, which provides for the prevention and detection of export-import operations in violation of customs legislation. High level of efficiency in detecting illegal foreign economic operations was achieved thanks to international information exchange with the customs administrations of foreign countries (Poland, Germany, the Kingdom of the Netherlands).In particular, according to the results of cooperation with the customs administration of the Kingdom of the Netherlands, it was revealed the illegal import of goods worth $569.3 \mathrm{mln}$ UAH using fraudulent schemes.

It should be noted that the SFS customs offices have the function of facilitating the protection of intellectual property rights at the customs border. During the analyzed period, 2.916 objects and 9.687 cases were registered 
in the customs register of intellectual property rights. SFS customs offices opened 14 cases of violation of customs rules on the facts of movement of goods with violation of intellectual property rights for a total amount of more than 10.5 mln UAH (Report on the implementation of the Work Plan of the State Fiscal Service of Ukraine for 2017).

Thus, according to the results of the analysis, it can be argued that the SFS customs offices of Ukraine occupy a leading place in the system of state authorities, which are charged with the task of state control over the compliance of economic operators with tax and customs legislation.

The analysis of indicators of customs offices functioning of the SFS of Ukraine in the sphere of foreign economic activity (FEA) allowed to determine the place of the customs system in ensuring economic security of Ukraine.

These indicators in general for Ukraine are generalized and do not disclose the specifics of customs activity in countering customs offenses at the same time. It is necessary to analyze in more detail the results of work to identify violations of customs legislation rules on the example of the Kyiv customs office of the SFS of Ukraine, which occupies a significant share in the structure of the total volume of customs clearance of goods in Ukraine.

Note that during 2015-2017 Kyiv customs office of the SFS of Ukraine has drawn up 2.364 records on violation of customs rules for a total amount of $1249.6 \mathrm{mln} \mathrm{UAH}$, as a result of which 1765 decisions were issued on the imposition of administrative penalties (fines) (Table 3). In particular, in $20162.1 \mathrm{mln}$ UAH was added to the budget the collection of fines.

Table 3. Counteraction to customs offenses of the SFS of Ukraine

\begin{tabular}{|c|c|c|c|c|c|c|c|c|}
\hline \multirow{3}{*}{$\begin{array}{l}\text { SFS customs } \\
\text { office }\end{array}$} & \multicolumn{2}{|c|}{$\begin{array}{c}\text { There have been } \\
\text { drawn up records on } \\
\text { violation } \\
\text { of customs rules }\end{array}$} & \multicolumn{3}{|c|}{$\begin{array}{l}\text { Based on the results of consideration of } \\
\text { administrative proceedings according to } \\
\text { the records were made on the imposition of } \\
\text { administrative penalties (fines) }\end{array}$} & \multicolumn{3}{|c|}{$\begin{array}{l}\text { Temporarily seized items } \\
\text { of offenses in the amount } \\
\text { of mln, UAH }\end{array}$} \\
\hline & \multirow[b]{2}{*}{ number } & \multirow{2}{*}{$\begin{array}{c}\text { in the } \\
\text { amount } \\
\text { mln UAH }\end{array}$} & \multirow{2}{*}{$\begin{array}{c}\text { number of } \\
\text { decisions }\end{array}$} & \multirow{2}{*}{$\begin{array}{l}\text { in the } \\
\text { amount } \\
\text { mln UAH }\end{array}$} & \multirow{2}{*}{$\begin{array}{l}\text { added to the budget } \\
\text { (from the collection } \\
\text { of fines) mln UAH }\end{array}$} & \multirow{2}{*}{$\begin{array}{l}\text { Industrial } \\
\text { goods }\end{array}$} & \multicolumn{2}{|c|}{ Food products } \\
\hline & & & & & & & $\begin{array}{c}\text { in the amount } \\
\text { mln UAH }\end{array}$ & $\begin{array}{c}\text { including } \\
\text { tobacco products }\end{array}$ \\
\hline \multicolumn{9}{|c|}{2015} \\
\hline $\begin{array}{l}\text { Kyiv customs } \\
\text { office SFS }\end{array}$ & 758 & 63,4 & 606 & 10,4 & 1,4 & 25,6 & 1,0 & 0,1 \\
\hline \multicolumn{9}{|c|}{2016} \\
\hline $\begin{array}{l}\text { Kyiv } \\
\text { customs } \\
\text { office SFS }\end{array}$ & 777 & 497,7 & 630 & 408,9 & 2,0 & 39,3 & 3,0 & 0,1 \\
\hline \multicolumn{9}{|c|}{2017} \\
\hline $\begin{array}{l}\text { Kyiv customs } \\
\text { office SFS }\end{array}$ & 829 & 688,5 & 529 & 25,8 & 2Д & 55,6 & 6,3 & 0,3 \\
\hline \multicolumn{9}{|c|}{$2015-2017$} \\
\hline $\begin{array}{l}\text { Kyiv customs } \\
\text { office SFS }\end{array}$ & 2364 & 1249,6 & 1765 & 445,2 & 5,5 & 120,5 & 10,3 & 0,5 \\
\hline
\end{tabular}

Source: confirmed by the author based on Report on the implementation of the Work Plan of the State Fiscal Service of Ukraine for 2017

One of the most effective indirect methods of customs control is the interaction with the customs authorities of foreign states, namely sending requests to other state authorities, institutions and organizations, authorized bodies of foreign states to establish the authenticity of documents submitted to the customs authority (Table 4). 
Table 4. Interaction with customs authorities of foreign states of SFS of Ukraine

\begin{tabular}{|c|c|c|c|c|}
\hline Year & Sent requests & Get answers & $\begin{array}{c}\text { Number of permanent residence } \\
\text { (permanent residence) }\end{array}$ & Amount, mln UAH \\
\hline 2015 & 73 (+4directly customs office) & 79 & 2 & 700 \\
\hline 2016 & 75 & 113 & 11 & 392.0. \\
\hline 2017 & 104 & 126 & 29 & 552.6 \\
\hline
\end{tabular}

Source: confirmed by the author based on Report on the implementation of the Work Plan of the State Fiscal Service of Ukraine for 2017

Generally, for the period of 2015-2017, the Department for countering customs offenses prepared 256 requests to the customs authorities of foreign countries, as well as processed 318 responses, the results of which were compiled 42 records on PR in the amount of $951.6 \mathrm{mln}$ UAH.

During customs clearance of goods using customs declarations on the form of a single administrative document, customs officials use an Automated system for customs clearance of goods. It is used to create a database of customs declarations and documents submitted together with them, check documents and information submitted to the revenue and customs authorities during the movement of goods, and commercial vehicles across the customs border of Ukraine, as well as to make appropriate marks in the electronic customs declaration or an electronic copy of the customs declaration submitted on paper, the fact of performing certain customs formalities. The automated customs clearance system is the part of the Unified automated information system of State fiscal service (UAIS SFS), which operates in accordance with the provision approved by the Ministry of Finance of Ukraine.

The introduction and development of such systems is associated with the effective use of such systems by the world leading customs administrations, the provisions of international conventions and customs legislation of Ukraine regarding the selectivity of customs control and the application of risk management systems.

Ensuring economic security in the sphere of FEA of Ukraine, including customs security, namely, it is indicated that the Ukrainian customs system during 2012-2017 has undergone significant organizational and structural changes, as a result of which, it was lost practice in such important areas of customs offices functioning as postaudit, customs statistics, protection of the Ukrainian market, etc. Despite a significant reduction in the number of customs officials and an unbalanced system of customs regulation, the customs offices of SFS of Ukraine provide about $45 \%$ of payments to the General Fund of the state budget.

In order to codify the rules of EU customs legislation, a Customs Code was adopted in 1992, replacing a large number of laws, thereby increasing the level of legislation transparency. The following amendments have been made in the period since the adoption of the Code:

1. The amendments adopted in 1997 have simplified the Code to improve effectiveness of its implementation in Member States. They relate to customs debt and free zone control, as well as the simplification of formalities around the customs declaration.

2. The amendments made in 1999 mainly concerned the customs transit. They clarify and improve the rules on the transit procedure and responsibilities of those entitled to use the procedure. They also cover financial guarantees and debt recovery procedures arising from Community transit operations.

3. The 2000 Amending Act introduced measures to: introduce fraud prevention procedures; simplification and rationalization of customs rules and procedures; facilitating the use of electronically filed declarations; facilitating the use of internal processing procedures, customs-controlled processing, temporary importation and free zones; defining a new concept of "good faith" protection for those who import goods on preferential terms.

4. The 2005 amendments aimed at strengthening the security requirements for the movement of goods across international borders. Economic operators are now obliged to provide the customs authorities with the requisites of goods before they are imported into or exported from the EU. The new concept Authorized Economic Operator (AEO) facilitates trade (Council Regulation (EEC) No 2913/92, 1992). 
On October 9, 2013 in accordance with Regulation (EU) No 952/2013 of the European Parliament and of the Council, a new Customs Code (hereinafter referred to as the EU CC) was adopted, which entered into force on October 30, 2013, The EU's customs territory began on May 1, 2016. In Art. 5 of the EU CC customs authorities are defined as the customs administrations of the Member States responsible for the application of customs legislation and any other authority empowered by national law to apply certain customs legislation. Art. 3 of the EU CC defined the mission of the customs authorities. According to the indicated provision, the customs authorities are primarily responsible for overseeing the EU's international trade, thereby promoting fair and open trade, implementation of external aspects of the internal market, the common trade policy and other common EU policies related to trade and the general security of the supply chain. The customs authorities take measures aimed in particular at:

(a) protection of the financial interests of the Union and its Member States;

(b) protecting the EU from fraudulent and illegal trade by supporting legitimate business activities;

(c) ensurng safety and security of the EU and its inhabitants and the environment, where appropriate, in close cooperation with other authorities; and

(d) maintaining a proper balance between customs control and facilitation of legal trade (Regulation (EU) No 952/2013, 2013).

An independent intergovernmental body whose mission is to improve the efficiency and effectiveness of customs administrations, is The World Customs Organization (WCO), which was established in 1952 as the Customs Co-operation Council (CCC). Today, WCO represents 183 customs administrations worldwide that together processes approximately $98 \%$ of world trade. As a global center of customs expertise, the WCO is the only international organization with competence in customs matters and can rightfully call itself the "voice" of the international customs community (The official website of the WCO).

In 2019 EU members approved a new Strategic Plan for the period 2019-2022 at the WCO Council sessions. It identifies nine priority areas for the implementation which should be focused by the WCO Secretariat: 1) Coordination of border management; 2) Security and Protection; 3) Revision of the Kyoto Convention; 4) E-commerce; 5) Harmonized System; 6) Strategy for capacity building; 7) Productiveness measurement; 8) Integrity and digital customs; 9) Data Analytics (WCO Strategic Plan for the 2019-2022, 2019).

It is important to note that within the framework of continuous efforts to strengthen customs border management, modernize customs operations and improve the institutional trading platform of Ukraine, the State Fiscal Service has undertaken a number of activities and detailed planning to achieve these goals. As part of this future planning, the WCO Strategic Planning Mission was conducted from May 21 to May 23, 2019. Representatives of the State Fiscal Service of Ukraine and one representative of the Ministry of Finance worked with WCO facilitators to develop the Strategic Plan Framework. Discussion and group work were about revising the vision, mission, values and strategic priorities to meet future needs. This review also covered risk responses, specific steps, timetables and performance indicators agreed with each of the strategic priorities (Ukraine State Fiscal Service Reviews Strategic Plan, 2019).

Within the framework of the investigated topics, we consider it appropriate to reveal the European experience of building a system of customs authorities, whose activity is aimed at ensuring the economic interests and security of the state, based on the example of Germany, UK and France.

In Germany, for example, financial issues are primarily at the constitutional level, and they are governed by the provisions of Section X of the Basic Law for the Federal Republic of Germany, 1949. The division of powers on the tax law is established by Art. 105, under which the Federation has the exclusive power to legislate on customs duties and fiscal monopolies (Basic Law for the Federal Republic of Germany, 1949).

Art. 108, which defines the issues of financial management of the Federation and lands, establishes the exclusive competence of Federal Financial Authorities in the management of customs payments, tax on the activity of financial monopolies, excise tax, which are regulated at the federal level, as well as income tax, value added 
tax, transport charge and other taxes on motorized vehicles within the European Union. In turn, management in the field of collecting other types of taxes is carried out by the financial authorities of the federal lands. The Federation may regulate the structure of these bodies, the procedure for their operation and the uniform training system based on federal law, which requires the approval of the Bundesrat (Basic Law for the Federal Republic of Germany, 1949).

The organizational structure of financial management is governed by the provisions of a separate legislative act - Gesetz über die Finanzverwaltung (Finanzverwaltungsgesetz - FVG) 1971. The federal tax authorities have a three-tier structure:

Level 1 - Federal Ministry of Finance (as the highest authority);

Level 2 - Federal Central Tax Administration and the Main Customs Administration (as higher authorities);

Level 3 - Major Customs Institutions, including their departments (customs) and customs investigations departments (as Local Authorities) (Finanzverwaltungsgesetz, 1971).

Customs institutions (HZÄ) as local authorities are the basis of the Federal Customs Administration. Subordinate Customs and Customs Authorities are the first point of contact for citizens and economic operators on all customs matters. The organizational structure is based on the tasks that HZÄ must perform. HZÄ employees cover the following activities:

1) general management - organization, staff, paying agent, other services;

2) customs duties and excise duties - market regulation, foreign trade legislation, origin of goods and privileges, bans and restrictions, remedies, deferred payments, and control over cash and money laundering;

3) customs clearance (adjustment of customs procedures of economic importance, adjustment of simplified procedures for the release of goods for free circulation), subsequent collection and refunds, processing of goods subject to excise duty;

4) external audit and tax oversight, mobile control groups and audit groups to combat illegal employment;

5) financial control over undeclared work - employees and employers' supervision in violation of trade and tax laws;

6) criminal cases and penalties - punishment for revealed violations of legal norms of customs and excise tax legislation, issuance of penal notices, preparation of punitive orders;

7) enforcement and penalty - taxes collection which are not paid voluntarily by the debtor (Hauptzollamt München).

The UK tax, payment and customs authority is HM Revenue \& Customs (HMRC), created under the Commissioners for Revenue and Customs Act (CRCA) in 2005. HMRC is a ministerial department subordinated to the Parliament and under the control of the Ministry of Finance. HMRC is responsible for both tax receipts (environmental, value-added, from capital, from inheritance, from insurance payments, land, oil, etc.) and duties payment. There are only 2 "Customs" departments from 72 ones in the HMRC structure: The Customs Department and the Customs Transformation Department. The main activities are: 1) collection of proper payments, including state fees, and reduction of cases of persons evasion from their payment; 2) changes in taxes and payments for clients; 3) development and maintenance of professional and efficient organization of activities (HM Revenue \& Customs).

The Direction generale des douanes et droits indirects (DGDDI) operates in France subordinated to the Ministry of Public Accounts. DGDDI performs three main tasks: 1) combating fraud; 2) support for economic activity; 3) promoting taxation. Customs is responsible for protecting the territory and citizens, national and public economic and financial interests (mobilization against drug trafficking, counterfeiting, tobacco, weapons, combating terrorism and financing criminal activity, combating environmental threats). Thanks to a deep knowledge of international flows to protect the country, DGDDI also supports the national economy and the French business. Based on the rules established for international trade, DGDDI monitors trade flows through procedures tailored to the needs of the business in three ways: speed; security; quality (L'essentiel de la douane). 
Customs promotes the protection and security of citizens by:

1) ensuring compliance with the quality / safety standards for industrial products imported from outside the EU (control of documents and products, laboratory tests);

2) fight against trade in narcotic drugs, weapons, cultural property, protected species of animals and plants;

3) monitoring the movement of toxic waste within the EU and preventing entering France strategic, radioactive, hazardous or non-standard products or counteracting marine pollution.

The customs collect in tax matters:

1) duties on imports into the European Union;

2) VAT, if it concerns products imported from third countries into the European Union;

3) excise duties, ie indirect taxes on tobacco, alcohol and petroleum products;

4) environmental taxation with General Tax on the Polluting Activities (TGAP) or internal tax on final electricity consumption (TICFE) (L'essentiel de la douane).

The organizational structure of the General Directorate for Customs and Indirect Taxes is as follows:

1) general management located in Montreuil;

2) decentralized services in mainland France and abroad: 12 interregional departments with territorial jurisdiction over administrative regions and 42 regional offices (each interregional department includes 3 or 4 territorial offices or coastguards);

3) specialized bodies:

- Directorate-General of Customs and Indirect Taxes (DNRED), responsible for the fight against major fraud and against criminal organizations;

- Judicial Finance Investigation Service (SEJF) specializing in tax crime repression - DGDDI / DGFiP Joint Service;

- National Customs Coast Guard (DNGCD), which implements the strategic guidelines established by the Customs in the maritime and air sectors;

- Joint Laboratory Service of DGDDI / DGCCRF (SCL);

- Analysis and Risk Orientation Service (SARC);

- National Directorate for Recruitment and Vocational Training (DNRFP);

- National Directorate of Foreign Trade Statistics (DNSCE);

- Customs and Computing center (CID);

- National Customs Museum in Bordeaux (MND) (Organization de la direction générale des douanes et droits indirects).

The Customs Code of Ukraine 2012 (hereinafter referred to as the CC of Ukraine) is the main codified normative legal act, which defines the principles of organization and implementation of customs affairs in Ukraine. The provisions of CC of Ukraine are intended to provide protection of economic interests of the state, creation of favorable conditions for the development of its economy, protection of the rights and interests of business entities and citizens, as well as ensuring compliance with Ukrainian customs legislation.

According to paragraph 34-1 of Part 1 of Art. 4 of CC of Ukraine Customs Authorities is the central body of executive power that implements state customs policy, customs and customs posts. The organizational structure, legal status and peculiarities of the activity of customs authorities are specified in section XX of the Customs Code of Ukraine. Customs authorities are directly responsible for the implementation of the customs affairs. The legislator defines the main tasks performed by the customs authorities in the course of customs affairs. Among them:

1) ensuring the correct application, strict compliance and prevention of non-compliance with the requirements of the customs legislation of Ukraine; 
2) ensuring fulfillment of the obligations stipulated by the international agreements of Ukraine on customs affairs concluded in accordance with the law;

3) creation of favorable conditions for facilitating trade, transit, increasing trade and passenger traffic across the customs border of Ukraine, taking measures together with the customs authorities of other countries to improve the procedure for the passage of goods, vehicles through the customs border of Ukraine, their customs control and customs clearance;

4) risk analysis and management to determine the forms and scope of customs control;

6) ensuring the customs payments, control of the calculation correctness, timeliness and completeness of their payment, application of measures for their enforcement;

7) application of the measures of customs-tariff and non-tariff regulation of foreign economic activity envisaged by law, control over the compliance with all established by law prohibitions and restrictions on the movement of certain types of goods across the customs border of Ukraine by all subjects of foreign economic activity and citizens;

8) perfoming control over compliance with rules for the movement of currency values across the customs border of Ukraine;

9) promoting the protection of intellectual property rights;

10) prevention and counteraction to smuggling, fight against violations of customs rules throughout the customs territory of Ukraine;

11) control over the activity of enterprises providing services on goods declaration, transportation and storage of goods moving across the customs border of Ukraine or under customs control;

12) conducting the Ukrainian classification of goods of foreign economic activity;

13) maintenance of customs statistics accounting and exchange of customs statistics with customs authorities of other countries;

14) verification (authentication) of certificates of origin of goods from Ukraine and issuance of certificates of origin in cases established by current international treaties;

15) exchange of documents and information (including electronic) with other state bodies of Ukraine, customs, law enforcement and other bodies of foreign states;

16) introduction, development and technical support of information, telecommunication and information-telecommunication systems and technologies in the customs affairs, automation of customs procedures;

17) implementation of international cooperation in the field of customs affairs, attraction of external resources to support the activities of customs authorities;

18) dog training of the customs authorities activity;

19) management of the objects of the customs authorities' infrastructure, construction of the customs border;

20) executing other statutory powers conferred on the customs authorities (Customs Code of Ukraine, 2012).

The central executive body, which implements the state customs policy, directs, coordinates and controls the activities of customs, performs other powers stipulated by the CC of Ukraine and other laws of Ukraine, within its powers it issues orders, organizes and controls their implementation (Customs Code of Ukraine, 2012). Such a body is the State Customs Service of Ukraine.

The legal status of the State Customs Service of Ukraine is separately regulated by the Regulation approved by the Cabinet of Ministers of Ukraine (Resolution of March 6, 2019). The activities of it are directed and coordinated by the Cabinet of Ministers of Ukraine through the Minister of Finance. The chairman heads the State Customs Service, who manager its activities, represents in relations with other bodies, enterprises, institutions and organizations in Ukraine and abroad. The approval of the maximum number of civil servants and employees is within the competence of the Cabinet of Ministers of Ukraine. In its turn, approvement the structures of the State Customs Service's apparatus are authorized by its Chairman, but it is obligatory in agreement with the Minister of Finance (Regulations on the State Customs Service of Ukraine, 2019). 
The territorial bodies of the State Customs Service include customs and specialized bodies. Customs is a customs body which ensures the fulfillment of the tasks assigned to the customs authorities within the area of its activity. Customs is a territorial body of the central body of the executive power, which implements the state customs policy, has a separate balance, accounts in the bodies that carry out treasury services of budgetary funds, stamp and stationery with the state emblem of Ukraine and with its denomination. Managers of customs are appointed to positions and dismissed from them by the head of the Central Body of Executive Power, realizing the state customs policy, in accordance with the legislation on civil service. Customs operates their activity on the territory of one, two or more administrative-territorial units of Ukraine. Areas of customs are determined by provisions on these customs. Creation, reorganization and liquidation of customs shall be carried out in the manner prescribed by law (Customs Code of Ukraine, 2012).

The customs post is a customs body which is a part of the customs as a structural unit and ensures the fulfillment of the tasks assigned to the customs authorities in the area of its activity. Zones of customs posts are determined by Regulations on these posts. Regulations on customs posts are approved by the leaders of the respective customs in agreement with the Central executive body, implementing the state customs policy. Creation, reorganization and liquidation of customs posts is carried out by the Central executive authority, implementing the state customs policy, in the manner prescribed by law. Leaders of customs posts are assigned to positions and are exempt from them by the head of the Central executive authority, realizing the state customs policy, in the manner prescribed by the legislation (Customs Code of Ukraine, 2012).

The current Ukrainian legislation establishes that the implementation of the State policy in the field of State customs, in the sphere of combating offences in the application of tax, customs legislation, and legislation on the payment of a single contribution of the State Fiscal Service of Ukraine (SFS). The legal status of the SFS is determined by the regulations on the State Fiscal Service of Ukraine approved by the Cabinet of Ministers of May 21, 2014, No 236. The competence of the SFS Chairman includes appointment and dismissal of heads of customs posts (Resolution of the Cabinet of Ministers of Ukraine no No 236, 2014).

Therefore, the current legislation stipulates that customs posts are territorial bodies of the State Fiscal Service in the respective regions of Ukraine. Creation, reorganization and liquidation of customs posts is carried out by the SFS, and appointment and dismissal of heads of customs posts is made by the chairman of the SFS.

It is important to emphasize that the process of establishing the State Customs Service in Ukraine was completed by 2020, which was marked by the adoption of the Regulation on the State Customs Service of Ukraine. Thus, the Cabinet of Ministers transferred the functions of customs policy implementation to the newly created State Customs Service in December 2019. The official launch of the "New Customs" was held on December 8, 2019, at the same time appropriate authorities of the SFS were transferred to the State Customs Service (New Customs).

The employees of the customs authorities, which are responsible for the organizational, legal, personnel, financial, logistical support of the activities of these bodies, are officials. Customs officials are civil servants. Customs authorities are employed by Ukrainian citizens who are 18 years old and able by their business and moral qualities, educational level and health status to perform the tasks assigned to these bodies. Tests may be established with admission to the service in accordance with the Law of Ukraine «On Civil Service». The legislator has also set some restrictions that make it impossible for a person to be employed by the customs authorities. In particular, these persons are: 1) recognized as incapacitated; 2) persons having a criminal record for a premeditated crime; 3) persons who, during the year preceding their application to the customs authority for employment, were held administratively responsible for committing corruption and other corruption-related offenses.

The system of professional education in the field of customs affairs includes:

1) training of specialists with higher education;

2) retraining of customs officers;

3) training of scientific and scientific-pedagogical personnel; 
4) improving the qualification of customs officers;

5) organization of training of employees of customs bodies without break from work.

Training, retraining and advanced training of customs officers is carried out in specialized educational institutions of the customs authorities and in a specialized body for specialized training and cynological support of the central body of executive power, which implements the state customs policy. Training of higher education specialists for customs authorities in particular areas can also be carried out at higher educational institutons of other sectoral subordination under the state order (Customs Code of Ukraine, 2012).

It is important to note that the CC of Ukraine contains a separate rule, which defines the peculiarities of cooperation of customs authorities of Ukraine with customs authorities of neighboring countries. In accordance with international treaties concluded according to the law, the customs authorities of Ukraine together with the customs authorities of the neighboring states may:

1) conduct joint customs control at the border crossing points of Ukraine;

2) harmonization in the procedure established by the law of time of customs control at border crossing points of Ukraine, procedures of customs control, customs clearance and mutual recognition of documents used by customs authorities to complete customs formalities;

3) carrying out joint actions aimed at preventing, detecting and stopping smuggling and violation of customs rules;

4) carrying out joint actions in accordance with the procedure established by law aimed at preventing, detecting and terminating offenses in the sphere of official activity of employees of the customs authorities of Ukraine and customs services of neighboring states;

5) carrying out other joint one-off or permanent measures on issues that, in accordance with the CC of Ukraine and other acts of the legislation of Ukraine, belong to the powers of the customs authorities;

6) exchange of information, including using information technologies and systems (Customs Code of Ukraine, 2012).

Among the recent events, it is important to note that a Single state information web portal "Single Window for International Trade" was created in March 2020 in order to allow the population accessing information on the activities of the State Customs Service of Ukraine. Individuals can use the following options on this portal:

1) view news;

2) to find information about customs statistics, queues at customs points, importation of a car, integrated customs tariff, classification of goods, data on invoices for payment of customs duties, etc.;

3) to check the customs declaration;

4) to file a complaint about the work of customs, etc. (The only state information web portal "A Single Window for International Trade").

\section{Discussion}

The long process of establishing the State Customs Service in Ukraine was completed by 2020, which was marked by the adoption of the Regulation on the State Customs Service of Ukraine. Thus, the Cabinet of Ministers transferred the functions of customs policy implementation to the newly created State Customs Service in December 2019. The official launch of the "New Customs" was held on December 8, 2019, at the same time appropriate authorities of the SFS were transferred to the State Customs Service (New Customs).

Part 5, Art. 547 of the CC of Ukraine notes that leaders of customs posts are assigned to positions and are exempt from them by the head of the Central executive authority, realizing the state customs policy, in the manner prescribed by the legislation (Customs Code of Ukraine, 2012). The central executive body implementing state customs policy today is designated the State Customs Service of Ukraine. Thus, the heads of customs posts should be appointed by the Head of the State Customs Service of Ukraine. At the same time, the Regulation on the State 
Fiscal Service of Ukraine is in force, according to subitem 18 of item 11 appointment and dismissal of heads of customs posts are within the competence of the head of the State Fiscal Service. Therefore, there is a discrepancy between the rules of the Regulations on the State Customs Service and the State Fiscal Service of Ukraine on the appointment of heads of customs posts, which needs to be resolved at the legislative level by eliminating the norm about appointment of heads of customs posts from the text of the Regulation on State Fiscal Service.

\section{Conclusions}

In the framework of the concept formed the theoretical and methodological aspects of economic security, systematized categorical-conceptual apparatus, developed principles, developed appropriate instrument and mechanism of balancing the interests of the state and business in the system of ensuring economic security in the sphere of FEA.

In the context of the research of the effectiveness of the economic security system in the sphere of SFS of Ukraine the author concludes that the results of organizational and structural changes in the tax-customs system of Ukraine during 2012-2018 resulted in a decrease in the effectiveness of the customs regulation system (lost practice in such important areas of customs offices functioning as post-audit, customs statistics, protection of the Ukrainian market) as well as an imbalance in the system of providing of simplification to SFS entities with security measures. It is summarized the modern instruments of the SFS customs offices aimed at identifying and preventing external threats to the economic security of the state.

In order to codify the rules of EU customs legislation, a Customs Code was adopted in 1992, replacing a large number of laws, thereby increasing the level of transparency of legislation. On October 9, 2013, a new Customs Code was adopted, defining in particular the concept of customs authorities and their mission. An independent intergovernmental body whose mission is to improve the efficiency and effectiveness of customs administrations, is the World Customs Organization (WCO), which was established in 1952 as the Customs Co-operation Council (CCC). Today, WCO represents 183 customs administrations worldwide that together processes approximately $98 \%$ of world trade. As a global center of customs expertise, the WCO is the only international organization with competence in customs matters and can rightfully call itself the "voice" of the international customs community.

Within the framework of the investigated topics, the European experience of building a system of customs authorities, whose activity is aimed at ensuring the economic interests and security of the state, was considered, on the example of Germany, UK and France. Customs institutions in Germany (HZÄ), including their departments and departments of customs investigation are engaged in the three-tier structure of the Federal tax authorities, where they occupy the third (lower) level. In the United Kingdom, HM Revenue \& Customs (HMRC) is the only public tax, payment and customs service which is sumultaniously responsible for both tax and customs duties. But there are only 2 "Customs" departments from 72 ones in the HMRC structure: The Customs Department and the Customs Transformation Department. Direction generale des douanes et droits indirects (DGDDI) operates in France in three main tasks: 1) fight against fraud; 2) support for economic activity; 3) promoting taxation. Customs is responsible for protecting the territory and citizens, national and public economic and financial interests.

The Customs Code of Ukraine 2012 (hereinafter referred to as the CC of Ukraine) is the main codified normative legal act, which defines the principles of organization and implementation of customs affairs in Ukraine. According to the $\mathrm{CC}$ of Ukraine Customs Authorities are the central body of executive power that implements state customs policy, customs and customs posts. The organizational structure, legal status and peculiarities of the activity of customs authorities are specified in section XX of the Customs Code of Ukraine. The central executive body implementing the state customs policy is the State Customs Service of Ukraine, whose legal status is separately regulated by the relevant Regulation. The territorial bodies of the State Customs Service include customs and specialized bodies. Customs is a customs body which ensures the fulfillment of the tasks assigned to the customs authorities within the area of its activity. Customs is a territorial body of the State 
Customs Service. The customs post is a customs body which is a part of the customs as a structural unit and ensures the fulfillment of the tasks assigned to the customs authorities in the area of its activity. Among the recent events, it is important to note that a Single state information web portal "Single Window for International Trade" was created in March 2020 in order to allow the population accessing information on the activities of the State Customs Service of Ukraine.

Promising direction for improving customs regulation in Ukraine is the development of a mechanism for balancing interests in the system of ensuring economic security in the field of SFS, which should be understood as a consistent set of appropriate organizational procedures, organizational-economic and legal measures, economic instruments to ensure economic security in the sphere of SFS on the bases of balancing the interests of the state and business. This mechanism is based on an approach according to which economic entities will be able to receive appropriate simplifications in exchange for openness and transparency of the SFS, that is: the higher the confidence degree, the less the intervention level of customs authorities in the process of foreign economic operations performance.

\section{References}

Basic Law for the Federal Republic of Germany (1949). As amended up to Act of March 28, 2019. URL: https://www.gesetze-im-internet. de/englisch_gg/englisch_gg.html\#p0598

Chehabeddine, M., Tvaronavičienè, M. (2020). Securing regional development. Insights into Regional Development, $2(1), 430-442$. http://doi.org/10.9770/IRD.2020.2.1(3)

Constitution of Ukraine (1996). As amended up to Act of January 01, 2020. URL: https://zakon.rada.gov.ua/laws/show/254\%D0\%BA/96$\% \mathrm{D} 0 \% \mathrm{~B} 2 \% \mathrm{D} 1 \% 80$

Council Regulation (EEC) № 2913/92 of 12 October 1992 establishing the Community Customs Code (1992). URL: https://eur-lex. europa.eu/legal-content/EN/TXT/?uri=LEGISSUM\%3A111010

Customs Code of Ukraine (2012). As amended up to Act of March 17, 2020. URL: https://zakon.rada.gov.ua/laws/show/4495-17

Fakhry, B., Aktan, B., Masood, O., Tvaronavičienè, M., Celik, S. (2018). The Impact Of A Recent Natural Disaster On The Japanese Financial Markets: Empirical Evidenece, Journal of Competitiveness 10(2): 56-71, ISSN 1804-171X (Print), ISSN $1804-1728$ (On-line), https://doi.org/10.7441/joc.2018.02.04

Finanzverwaltungsgesetz - FVG (1971). As amended up to Act of December 21, 2019. URL: http://www.gesetze-im-internet.de/ fvg_1971/BJNR014270971.html

Hauptzollamt München (HZA München). URL: https://www.service.bund.de/Content/DE/DEBehoerden/H/HZA/HZA-Muenchen/ Hauptzollamt-Muenchen.html?nn=4641496

HM Revenue \& Customs. URL: https://www.gov.uk/government/organisations/hm-revenue-customs/about

Kryvytsky, V. (2018). The conceptual basis of the paradigm of customs security in Ukraine. Svit finansiv, 4(57), 99-109.

L'essentiel de la douane. Le portail de la direction générale des douanes et droits indirects. URL: https://www.douane.gouv.fr/la-douane/ qui-sommes-nous/lessentiel-de-la-douane

Levko, M.M. (2016) Systematic Approach to Identifying the Role and Place of Customs Safety in the Economic Safety of the State. Naukovyi visnyk Natsionalnoho lisotekhnichnoho universytetu Ukrainy, 26(2), 95-103. https://doi.org/10.15421/40260216

Lincényi, M., Čársky, J. (2020). Policy trusts in public policy in the Slovak Republic. Insights into Regional Development, 2(1), 456-468. http://doi.org/10.9770/IRD.2020.2.1(5)

New Customs. The official website of the State Customs Service of Ukraine. URL: http://www.customs.gov.ua

Organisation de la direction générale des douanes et droits indirects. Le portail de la direction générale des douanes et droits indirects. URL: https:/www.douane.gouv.fr/la-douane/qui-sommes-nous/organisation-de-la-direction-generale-des-douanes-et-droits-indirects

Plèta, T., Tvaronavičienè, M., Della Casa, S. (2020). Cyber effect and security management aspects in critical energy infrastructures. Insights into Regional Development, 2(2), 538-548. https://doi.org/10.9770/IRD.2020.2.2(3) 
Popivniak, O.I. (2018). On the definition of customs security in theory and legislation. Visnyk NTUU «KPI», 1(37), 87-91. https://doi. org/10.20535/2308-5053.2018.1(37).152864

Pudrik, D.V. (2016). The concept of «customs security» in modernlegal science. Naukovyi visnyk Mizhnarodnoho humanitarnoho universytetu. Ser. Yurysprudentsiia, 24, 106-108.

Razumova, O. (2019). Customs security concepts in the context of Ukraine's national security. Pidpryiemnytstvo, hospodarstvo i pravo, 3, 165-158.

Regulation (EU) № 952/2013 of the European Parliament and of the Council of 9 October 2013 laying down the Union Customs Code (2013). As amended up to Act of January 01, 2020. URL: https://eur-lex.europa.eu/legal-content/EN/TXT/?uri=CELEX:0201 3R0952-20200101

Regulations on the State Customs Service of Ukraine (2019). As amended up to Act of September 27, 2019. URL: https://zakon.rada.gov. ua/laws/show/227-2019-\%D0\%BF

Resolution of the Cabinet of Ministers of Ukraine № 236 On the State Fiscal Service of Ukraine (2014). As amended up to Act of September 27, 2019. URL: https://zakon.rada.gov.ua/laws/show/236-2014-\%D0\%BF

Reznik, O., Muzychuk, O., Andriichenko, N., Yakushchenko, Y., \& Korzh, S. (2020). Fight Against Doping: Experience of Ukraine and European States. Amazonia Investiga, 9(27), 34-41. https://doi.org/10.34069/AI/2020.27.03.4

Šincāns, E., Ignatjeva, S., Tvaronavičienè, M. (2016), Issues of Latvian Energy Supply Security: Evaluation of Criminal Offences in Latvia's Electricity Market, Economics and Sociology, 9(4), 11-25. http://dx.doi.org/10.14254/2071-789X.2016/9-4/1

The official website of the World Customs Organization (WCO). URL: http://www.wcoomd.org/

The only state information web portal «A Single Window for International Trade». URL: https:/cabinet.customs.gov.ua/

Tvaronavičienė, M. (2018). Preconditions of sustainable entrepreneurship: estimating of Brexit scenarios' impact on macroeconomic environment. Polish Journal of Management Studies, 17(2), 222-234 https://doi.org/10.17512/pjms.2018.17.2.19

Ukraine State Fiscal Service reviews Strategic Plan to prepare for changes and implementation of the WTO Trade Facilitation Agreement (2019). The official website of the WCO. URL: http:/www.wcoomd.org/en/media/newsroom/2019/may/ukraine-state-fiscal-servicereviews-strategic-plan.aspx

WCO Strategic Plan for the 2019-2022 (2019). URL: http://www.wcoomd.org/-/media/wco/public/global/pdf/about-us/administrativedocuments/wco-strategic-plan-2019-2022.pdf?db=web

Dmytro ZHURAVLOV

ORCID ID: orcid.org/0000-0002-2045-9631

Ivan LYTVYN

ORCID ID: orcid.org/0000-0002-4180-7500

Oleksandr ILCHENKO. PhD in Law, Head of the Department of the Special Unit for Combating Corruption and Organized Crime of the Security Service of Ukraine in Lviv Region.

ORCID ID: orcid.org/0000-0003-4885-2205

\section{Ivan YAROMII}

ORCID ID: orcid.org/0000-0002-3801-3742

\section{Yuliia LEPEKH}

ORCID ID: orcid.org/0000-0003-4530-4924

This work is licensed under the Creative Commons Attribution International License (CC BY). http://creativecommons.org/licenses/by/4.0/ 